\title{
Nitrogen and phosphorus as limiting factors for growth and primary production in a flooded savanna in the Venezuelan Llanos
}

\author{
Guillermo Sarmiento ${ }^{1}$, Marta Pereira da Silva ${ }^{2}$, Maria Elena Naranjo and Marcela Pinillos ${ }^{3}$
}

Instituto de Ciencias Ambientales y Ecológicas, Universidad de los Andes, Mérida, Venezuela

(Accepted 15 September 2005)

\begin{abstract}
The effects of N, P, NP and NPKS application on plant growth, above-ground primary production and $\mathrm{N}$ and $\mathrm{P}$ accumulation in the above-ground biomass of a flooded savanna were assessed over two growth cycles. Application of $\mathrm{N}$ or $\mathrm{P}$ did not improve plant growth and primary production, addition of NP had a noticeable effect, whereas NPKS fertilization led to a three-fold increase in plant production. The four most important grasses in the analysed ecosystem responded to nutrient application with increasing growth, indicating that they all are constrained by nutrient availability, but each species exhibited a different seasonal growth pattern suggesting a temporal division of nutrient resources. $\mathrm{N}$ accumulated in the harvested biomass during the growth season was $50 \%$ above that of control plants when NP was applied and showed a four-fold increase when NPKS was added. With NP addition, in 2 mo plants accumulated three times more $\mathrm{P}$ in the harvested biomass than the control plants. The maximum $\mathrm{N}$ accumulated during the growth season in the NPKS treatment represented half the fertilizer N, and probably all the N added ( $15 \mathrm{~g}$ $\mathrm{m}^{-2}$ ) may have been used if the whole biomass had been considered. With the rather small amounts of $\mathrm{P}$ added to the soil in the $\mathrm{P}$ treatment $\left(2 \mathrm{~g} \mathrm{~m}^{-2}\right)$, the maximum amount of $\mathrm{P}$ accumulated after 2 mo scarcely represented $13 \%$ of the added $P$, suggesting that most of the fertilizer $P$ became rapidly immobilized or sorbed, not being available to plants in the short term. However, the increasing growth rates of grasses during the following 7 mo indicate that some $\mathrm{P}$ fluxed from these pools to the soil solution and to plants.
\end{abstract}

Key Words: grasses, hyperseasonal savanna, nutrient limitation, P sorption, tropical grassland

\section{INTRODUCTION}

Seasonally flooded savanna extends over large areas in South America, particularly in the Llanos of Colombia and Venezuela, the Gran Pantanal in Brazil, Paraguay and Bolivia, and the Llanos de Moxos or Beni in Bolivia (Sarmiento 1983a). Despite its widespread occurrence, it is one of the poorly known tropical ecosystems, maybe because it is rather unfriendly during the rains, when most of the landscape remains inaccessible, and it is difficult to analyse during the dry season, when the soils becomes rock hard and the savanna is covered with easily flammable standing-dead plant material.

This kind of tropical savanna has been termed hyperseasonal savanna because its highly contrasting

\footnotetext{
${ }^{1}$ Corresponding author. Email: sguille@ula.ve. Instituto de Ciencias Ambientales y Ecológicas - ICAE, Facultad de Ciencias, Universidad de los Andes, Núcleo La Hechicera, Mérida 5101, Mérida, Venezuela.

${ }^{2}$ Present address: Centro Nacional de Pesquisa do Gado de Corte, CNPGCEMBRAPA, Campo Grande, MS, Brazil.

${ }^{3}$ Present address: Programa de Pós-graduação em Ecología, Universidade Federal de Río Grande do Sul, Porto Alegre, RS, Brazil.
}

soil water regime arising from a sharp rainfall seasonality coupled with a level topography and, at least in the Apure Llanos, with the widespread occurrence of an almost impermeable clay pan at $50-100 \mathrm{~cm}$ in depth (Sarmiento 1984, Sarmiento \& Pinillos 2000). During the rainy season, monthly precipitation may exceed $400 \mathrm{~mm}$, while the 4-5-mo dry season is almost rainless. The transition between the two contrasting periods is rapid, a few weeks after the onset of rains soils become water saturated and soon most of the landscape becomes waterlogged or flooded by the almost stagnant rainwater. With the end of the rainy season, the soil and the vegetation quickly dry out. The growth season for grasses and herbs extends for the 7-8 mo of the rainy season, from AprilMay to November-December, depending on the rainfall of any particular year, but even this favourable season is interrupted by an extended period of water excess, when most species slow down or stop growing.

In the Venezuelan Llanos, flooded savannas are used as extensive rangelands for livestock production. Stocking rates are low, limited by the seasonality of grass growth and the poor forage quality of savanna grasses. In fact, the dominant grass species have fairly high crude protein 
content when growth is triggered by the first rains, but they rapidly become less palatable and digestible as the above-ground biomass ages and dries out (Fisher et al. 1992).

In a previous paper we analysed the effects of water availability and grazing on the production processes of this savanna ecosystem showing that plant growth virtually ceases during the dry season and also at the peak of inundation, being mostly restricted to the two short transitions between the wet and dry seasons (Sarmiento et al. 2004). The moderate grazing pressure does not seem to affect plant production.

Apart from the effect of the annual soil water regime, a further point concerning the overall ecological behaviour of flooded tropical savannas relates to the consequences of the highly dystrophic soils and how the scarcity of available nutrients combines with the water excess constraint. All humid savannas seem to be mainly determined by the interactions between soil water regime and nutrient availability, with feedbacks from species and vegetation responses affecting fire occurrence and grazing (Medina \& Silva 1990, Sarmiento 1984, Solbrig et al. 1995). In particular, we want to know the effects of a temporary lessening of nutrient limitation through the application of a moderate pulse of possible limiting elements, like N, P, K and S. Besides, we want to explore the hierarchical interaction of $\mathrm{N}$ and $\mathrm{P}$ availability on aboveground primary production (ANPP) that is whether $\mathrm{N}$ or $\mathrm{P}$ is the primary limiting factor to plant growth, as has been analysed for other natural grasslands (Fynn \& O'Connor 2005). The main goals of this research are, firstly to analyse the interactions between water excess and nutrient constraints upon plant growth and primary production of a flooded savanna, secondly to disclose the role played by $\mathrm{N}$ and $\mathrm{P}$ in limiting grass growth, and thirdly, to uncover possible differences in the responses of the dominant grass species to a pulse of soil nutrients.

Well-drained savannas on old alluvial materials in the Venezuelan Llanos may be N-limited, mainly because legume species are neither numerous nor conspicuous, and also because of $\mathrm{N}$ losses during vegetation burning (Frost \& Robertson 1987, Medina 1987). Flooded savanna communities in this region maintain still fewer legume species, and just a couple of these legumes reaches a significant cover or biomass, mainly as weeds in overgrazed areas (Ramia 1997). In turn, the scarcity of legumes is probably due to the low levels of soil $\mathrm{P}$ hindering the symbiotic mechanisms, as hypothesized by Medina (1987). Free-living N-fixation seems to be low due to similar causes. Therefore, nitrogen fixation is unimportant as a source of this element for savanna plants. Fire is as frequent an event in hyperseasonal savannas as it is in the well-drained communities. Furthermore, under the anoxic conditions of extended waterlogging, denitrification contributes to the loss of soil nitrogen as is the case in freshwater marshes and similar wetlands (Delaune et al. 1986). Low N inputs and high outputs have probably led to a generalized $\mathrm{N}$ deficiency in flooded savanna soils.

A similar situation is met with P limitation. In humid ecosystems with acid, weathered soils, chemical reactions with iron and aluminium oxides and hydroxides stabilize $\mathrm{P}$ in a rather complex process termed sorption (Frossard et al. 1995). Some of these chemical P-Fe and P-Al bonds are weak, and this sorbed $\mathrm{P}$ may be desorbed by roots, mycorrhizas and other soil micro-organisms, but when the bonds are strong, this $\mathrm{P}$ pool becomes almost inaccessible to living organisms and very little $\mathrm{P}$ is maintained in the soil solution. In highly acidic, weathered tropical savanna soils, such as the oxisols in the Brazilian cerrados, total $\mathrm{P}$ in the topsoil ranges between 200 and $350 \mathrm{ppm}$ (Goedert 1986), with similar amounts being found in alfisols in the Venezuelan Llanos (Hétier et al. 1992). Hyperseasonal savanna soils are equally poor in total and plant-available P. Total $\mathrm{P}(0-10 \mathrm{~cm})$ ranges from $250-270 \mathrm{ppm}$, equivalent to about $30 \mathrm{~g} \mathrm{~m}^{-2}$, of which $75 \%$ is organic, 28 ppm is P-Fe and 12 ppm P-Al, and only 1 ppm is soluble $\mathrm{P}$ (Lopez-Hernández 1995). We may expect therefore, that any additional soluble P supply will positively affect plant growth and primary production if savanna grasses were able to compete for the additional $\mathrm{P}$ with the microbial biota and with the sorption sites in soil minerals. If not, most or all the extra $\mathrm{P}$ will be either immobilized or adsorbed. In the first case it might be available to plants after microbial decay, but in the second case, the tightly adsorbed P might be biologically available just in the very long term (Buehler et al. 2002). Within this framework of N, P, and probably also K and S shortage, we will try to analyse our results, discussing the fate of the added nutrients and the probable role of geochemical and biological fixation, in the light of what is known about other tropical ecosystems on similar dystrophic soils.

\section{STUDY AREA}

The study area is located in Hato El Frío, a cattle-raising ranch in Apure State, south-western Venezuela. The longterm rainfall average is $1466 \mathrm{~mm}, 90 \%$ of which falls between May and October. Mean monthly temperatures attain $27^{\circ} \mathrm{C}$, exhibiting negligible seasonal changes. The experimental plots were set out in a large, fairly homogeneous tract of hyperseasonal savanna, on midQuaternary alluvium, on which acid, dystrophic, highly weathered soils are evolving (tropaqualfs and tropaquults), having low values of total $\mathrm{N}$ and minimum amounts of extractable $\mathrm{P}$ and exchangeable $\mathrm{K}$ (Table 1).

This savanna is continuously and extensively grazed by cattle, mostly steers, with a stocking rate of about 0.4 head ha $^{-1}$. Only during the dry season and at the 
Table 1. Selected chemical properties of hyperseasonal savanna soils in the Apure Llanos, Venezuela. Data from Schargel \& González (1972) and Sarmiento et al. (2004).

\begin{tabular}{lcccccc}
\hline & Depth $(\mathrm{cm})$ & $\mathrm{pH}$ water $1: 1$ & $\mathrm{C}\left(\mathrm{g} \mathrm{kg}^{-1}\right)$ & $\mathrm{N}\left(\mathrm{g} \mathrm{kg}^{-1}\right)$ & $\mathrm{P}^{*}(\mathrm{ppm})$ & $\mathrm{K}_{\left(\mathrm{cmol} \mathrm{kg}^{-1}\right)}$ \\
\hline Ultic tropaqualf & $0-12$ & 4.8 & 19.1 & 1.1 & 20 & 0.27 \\
Hato El Frío & $12-27$ & 4.7 & 8.3 & 0.5 & 18 & 0.07 \\
Vertic tropaqualf & $0-22$ & 5.1 & 15.0 & 0.8 & 10 & 0.01 \\
Mantecal & $22-41$ & 5.6 & 5.7 & 0.3 & 3 & 0.01 \\
Typic plinthaquult & $0-26$ & 4.9 & 5.1 & 0.3 & 28 & 0.07 \\
Mantecal & $26-46$ & 5.2 & 0.8 & 0.1 & 20 & 0.03 \\
Aeric tropaqualf & $0-13$ & 4.2 & 9.4 & 0.5 & 26 & 0.09 \\
Bruzual & $13-27$ & 4.4 & 4.2 & 0.2 & 19 & 0.05 \\
\hline
\end{tabular}

* Extractable with citric acid.

peak of flooding, cattle move to lower or higher lands covered either by permanently humid wetlands or by seasonal, non-flooded savannas respectively (Sarmiento \& Pinillos 2000, 2001). The savanna burns each year, before the onset of rains, fire consumes practically all the above-ground standing-dead material triggering the rapid re-growth of grasses as soon as the soil becomes moist enough with the first rains.

From a physiognomic viewpoint, this savanna is almost pure grassland with isolated shrubs or low trees. Although it is fairly diverse, with 15-20 species of herbs and grasses in $100 \mathrm{~m}^{2}$ (Sarmiento et al. 2004), only three grass species reach a high cover in the area: Paspalum chaffanjonii Maury, Panicum laxum Sw. and Leersia hexandra Sw., the first being the dominant species in the experimental plots. Cattle have a definite preference for another frequent grass, Axonopus purpusii (Mex.) Chase, which consequently maintains a low cover under the actual grazing pressure to rapidly expand when grazing is excluded.

\section{METHODS}

Four $10 \times 10$-m experimental plots, randomly chosen within the large savanna tract, but having vehicle accessibility during most of the year, were fenced to exclude cattle grazing. For statistical analysis each plot was considered as a replicate. Two experiments were carried out. In the first one, the above-ground biomass was clipped at $10 \mathrm{~cm}$ high in April, at the start of the growth season. Afterwards NPKS was applied $\left(15 \mathrm{~g} \mathrm{~m}^{-2}\right.$ $\mathrm{N}$, as urea, $10 \mathrm{~g} \mathrm{~m}^{-2} \mathrm{P}$ as super-phosphate, $10 \mathrm{~g} \mathrm{~m}^{-2} \mathrm{~K}$ as $\mathrm{KCl}$, and $10 \mathrm{~g} \mathrm{~m}^{-2} \mathrm{~S}$ as $\mathrm{S}$ ), to one $5 \times 10-\mathrm{m}$ subplot in each plot. Monthly sampling was started in May and extended to December. Plant biomass above $10 \mathrm{~cm}$ high was harvested with a knife, in four random $0.25-\mathrm{m}^{2}$ quadrats per treatment (fertilized and control). After each sampling, the whole plot was clipped at the same height and the clipped material discarded. In this way the simultaneous effects of fertilization and 30-d clipping were assessed. Harvested material per quadrat was then separated according to the four main grass species, while all other plant species were lumped together. Each fraction was oven dried and weighed. The sum of the values for the four $0.25-\mathrm{m}^{2}$ quadrats per plot and treatment was taken as the harvested biomass per $\mathrm{m}^{2}$, either for each species or for the total, green biomass plus standing dead, thus obtaining a single value by treatment and plot, and four replicates per sampling date.

Above-ground biomass below $10 \mathrm{~cm}$ high was sampled through four random $0.25-\mathrm{m}^{2}$ quadrats by treatment and plot, at the start and at the end of the growth cycle, but it was not subdivided by species. The four samples were summed to obtain a single value for $1 \mathrm{~m}^{2}$, then the plant material was oven dried to constant weight. As the start value taken in April, immediately after burning, was negligible, we considered the final amount of the 0-10-cm layer plus the total harvested biomass above $10 \mathrm{~cm}$ as the savanna ANPP during the growth season $(225 \mathrm{~d})$. The separation of the above-ground biomass above and below $10 \mathrm{~cm}$ was done to determine the effects of the treatment on the monthly production of potentially available forage to livestock, under the conditions of moderate grazing pressure prevailing in this savanna. Below-ground biomass $(0-20 \mathrm{~cm})$ was sampled at the start and end of the growth season in four $10 \times 10-\mathrm{cm}$ pits, by treatment and plot, at the same above-ground biomass sampling dates. Soil samples $(0-10 \mathrm{~cm})$ were taken at each date to be analysed for mineral nitrogen. Nitrogen concentration in the harvested biomass of the most abundant species, Paspalum chaffanjonii, was determined for each sampling date. Soil mineral nitrogen $\left(\mathrm{NH}_{4}+\mathrm{NO}_{3}^{-}\right)$and $\mathrm{N}$ concentration in the harvested plant material was determined by the Kjeldahl method: digestion with $\mathrm{H}_{2} \mathrm{SO}_{4}$, distillation and titration with $\mathrm{NaOH}$ (AOAC 1990).

A second experiment, to evaluate the effects of $\mathrm{N}, \mathrm{P}$, and NP addition on plant growth and primary production, was performed the following year. Four randomly chosen $10 \times 20$-m plots were subdivided into four $5 \times 10-\mathrm{m}$ subplots to which fertilization treatments were randomly assigned. Fertilization treatments consisted of the addition of: $5 \mathrm{~g} \mathrm{~m}^{-2} \mathrm{~N}$ as urea, or $2 \mathrm{~g} \mathrm{~m}^{-2} \mathrm{P}$ as super-phosphate, or 
$5 \mathrm{~g} \mathrm{~m}^{-2} \mathrm{~N}+2 \mathrm{~g} \mathrm{~m}^{-2} \mathrm{P}$, with a fourth unfertilized subplot left as control. Nutrients were added in April, before the onset of the rainy season, and again in similar amounts, in October, after the period of soil water excess. Plots were sampled at 0,30 and $60 \mathrm{~d}$ after fertilization. As in the first experiment, four $0.25-\mathrm{m}^{2}$ quadrats were clipped monthly at $10 \mathrm{~cm}$ high, but the remaining area of the plot was not clipped, except when the fertilizer was applied, since in this experiment we just intended to evaluate the effect of fertilizer application and not of frequent clipping. We took care not to harvest the same quadrat twice or more through the year. Since the initial above-ground biomass remaining after fire was negligible, the final biomass above-ground biomass accumulated during a given month was considered as the ANPP of this savanna layer. $\mathrm{N}$ concentration in the harvested biomass was determined monthly after the initial fertilization as in the first experiment. $\mathrm{P}$ was mineralized by acid digestion in $\mathrm{H}_{2} \mathrm{SO}_{4}+\mathrm{HClO}_{4}$ and then quantified by molecular absorption in the visible wavelength.

Two-way analyses of variance (ANOVA) with randomization tests were used (Manly 1997, Pillar 2004), to evaluate the significance of differences in harvested biomass, soil mineral $\mathrm{N}$, plant $\mathrm{N}$ concentration and plant $\mathrm{P}$ concentration, among dates and treatments in both experiments. The statistical analyses were performed using the software MULTIV (Pillar 2004), with random permutations of vectors of raw data restricted within the groups, as defined by other factors than that whose significance was tested, and unrestricted permutation of residuals, after factor effects removal, to test the significance of interaction (Pillar 2004). In each case, significance was declared when the probability to obtain by chance a pseudo-F value equal or higher than the observed $\left(\mathrm{PF}_{\text {Null }} \leq \mathrm{F}_{\text {obs }}\right)$, was smaller than $\alpha$. The pseudo-F statistic, according to Pillar \& Orlóci (1996), was calculated as the ratio of the sum of squares between groups on the sum of squares within groups. For paired comparisons, a similar randomization procedure was followed, but restricting permutations to the groups defined in the contrast. When interaction was significant, paired contrasts between groups of one factor were restricted within the levels of the other factor (Pillar 2004).

\section{RESULTS}

In the first experiment, where NPKS was added, the effect of fertilization on yield was quite remarkable and it persisted from June to October (Figure 1). In the fertilized treatment the sum of cropped biomass, the ANPP of this layer, was three times higher than in the control $\left(2505 \pm 816\right.$ and $853 \pm 246 \mathrm{~g} \mathrm{~m}^{-2}$ respectively). The growth-promoting effect of fertilization was evident in all four dominant grasses (Figure 2), with significant

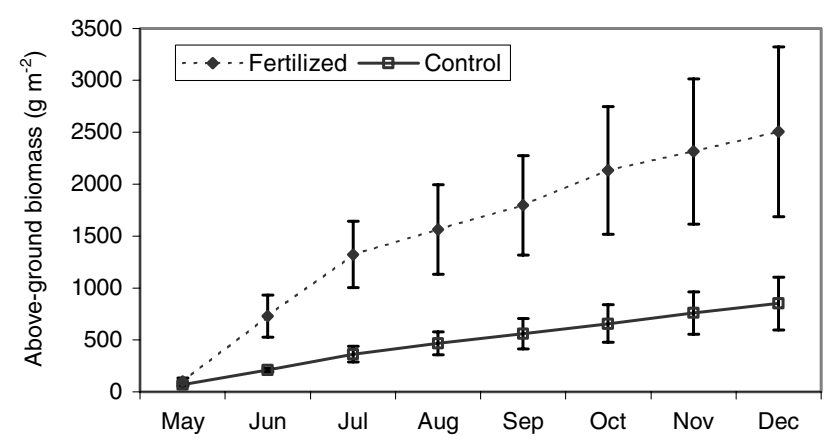

Figure 1. Cumulative yield (mean $\pm \mathrm{SD}$ ) of fertilized and control plots of a seasonally flooded savanna at Hato El Frío, Apure State, Venezuela, during the growth season (May-December). The savanna was burnt in April and fertilizer was applied a few days afterward $\left(15 \mathrm{~g} \mathrm{~N} \mathrm{~m}^{-2}\right.$ as urea, $10 \mathrm{~g} \mathrm{P} \mathrm{m}^{-2}$ as super-phosphate, $10 \mathrm{~g} \mathrm{~K} \mathrm{~m}^{-2}$ as KCl, and $10 \mathrm{~g} \mathrm{~S} \mathrm{~m}^{-2}$ as S). $P\left(F_{\text {null }} \geq F_{\text {obs }}\right)$ for treatment, dates and interactions were 0.0005 in all cases. As interaction was highly significant, paired comparisons between fertilization and control were performed within months, giving significant differences in yield for June, July, September and October.

differences between treatments, dates and interactions in Paspalum chaffanjonii $(\mathrm{P}=0.001)$, between interactions in Panicum laxum and between treatments and dates in Leersia hexandra, while the test cannot be done for Axonopus purpusii because it occurred in just one plot. The remaining species taken as a single set exhibit neither a definite growth pattern nor a clear response to fertilization (not shown), surely because of the heterogeneity of this group.

Above-ground plant biomass below clipping height $(10 \mathrm{~cm})$ did not differ significantly between treatments, attaining a final biomass of $79.7 \pm 26.1 \mathrm{~g} \mathrm{~m}^{-2}$ in fertilized and $54.4 \pm 11.4 \mathrm{~g} \mathrm{~m}^{-2}$ in the control plots. The net increase in below-ground biomass $(0-20 \mathrm{~cm})$ during the growing season was slightly lower in the fertilized treatments $\left(827 \pm 555 \mathrm{~g} \mathrm{~m}^{-2}\right.$ vs. $\left.1180 \pm 358 \mathrm{~g} \mathrm{~m}^{-2}\right)$, but due to the high between-plot variability, this difference was not statistically significant.

Soil mineral nitrogen did not differ significantly between treatments at any date. In both, it increased during the peak of the rainy season, from July to October, to decrease afterwards down to the initial values. In any case, the amounts between 4 and 10 ppm may be considered as relatively low. $\mathrm{N}$ concentration in the cropped biomass of $P$. chaffanjonii was significantly higher in fertilized plants during the $3 \mathrm{mo}$ following fertilizer application. The amount of $\mathrm{N}$ in the harvested biomass (Figure 3) was consistently higher in fertilized plants, the total $\mathrm{N}$ accumulated in yield was more than 4 -fold larger in the NPKS treatment than in the control, though the significance of these figures was not tested given that they are the product of cropped biomass (Figure 2) by $\mathrm{N}$ concentration, the significance of which was already tested.

In the second experiment, aimed at investigating the individual effects of $\mathrm{N}$ and $\mathrm{P}$, differences between treatments, 

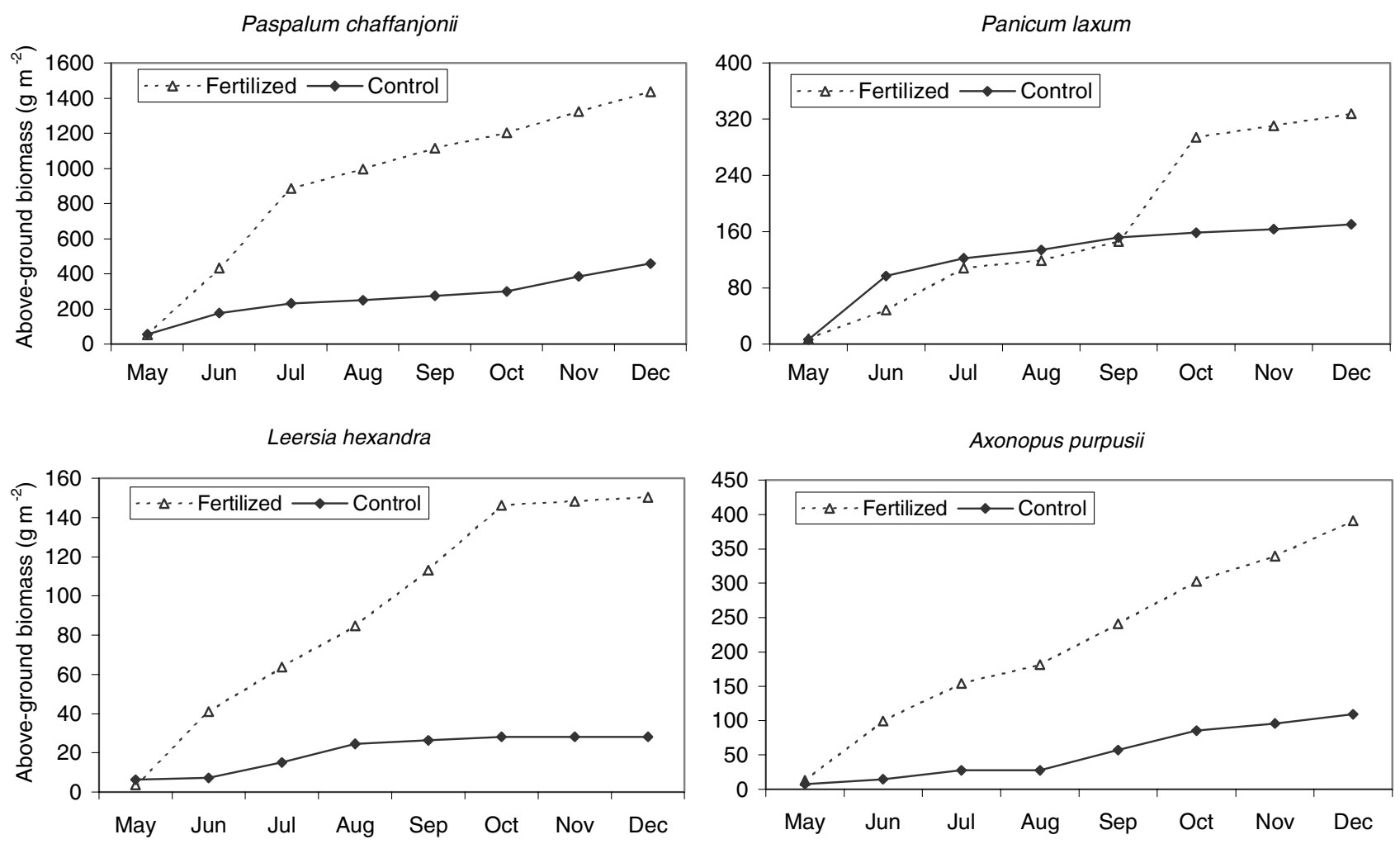

Figure 2. Cumulative yield of the four co-dominant grasses in fertilized and control plots of a seasonally flooded savanna at Hato El Frío, Apure State Venezuela, during the growth season (May-December). For the amounts of applied fertilizer see legend to Figure 1.

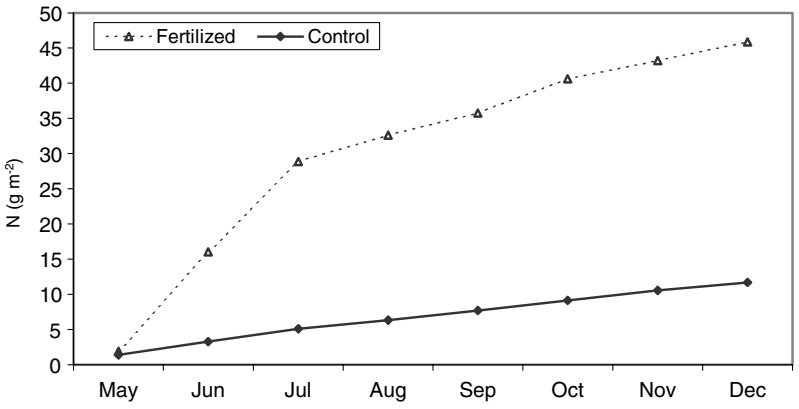

Figure 3. Total nitrogen accumulated in the harvested biomass of Paspalum chaffanjonii, the leading dominant grass in the studied vegetation. $15 \mathrm{~g} \mathrm{~N} \mathrm{~m}^{-2}$ was added in fertilizer.

dates and interactions were highly significant. All treatments attained a similar biomass in November, $7 \mathrm{mo}$ after the first nutrient addition, but their seasonal growth pattern during this period was quite different (Figure 4). Thus, the N and NP treatments attained a large biomass in 2 mo, while the P treatment showed at that time the smallest biomass, even below that of the control, to only reach the biomass amount of the other three treatments in November. Yield of NP-plots was significantly above that of N-plots only in May, while the yield of the P-plots was significantly below the control in both May and June (Figure 4). After the second nutrient addition in November, differences between treatments were not significant either 30 or $60 \mathrm{~d}$ after fertilizer application.

Nitrogen concentration in $P$. chaffanjonii showed significant differences between dates and significant interaction terms (Table 2). The N- and NP-plots attained a peak in $\mathrm{N}$ concentration 1 mo after the two fertilizations, but thereafter $\mathrm{N}$ concentrations fell below the $\mathrm{C}$-plots. The P-plots showed a similar behaviour but neither the initial increase nor the following decrease were as drastic as in the N-plots.

Phosphorus concentration in June gave significant differences between treatments and species (Table 3). In $P$. chaffanjoni and P. laxum, $\mathrm{P}$ concentration in the NP treatment was above the concentration in control plants. Leersia hexandra was the sole grass showing a significant increase in $\mathrm{P}$ concentration in the P-plots while A. purpusii showed increased $\mathrm{P}$ concentrations in the $\mathrm{N}$ - and P-plots.

\section{DISCUSSION}

\section{Growth and production}

The dominant grasses in this flooded savanna are strongly nutrient-limited since they rapidly respond to moderate amounts of NPKS supplied to the soil at the start of the growing season, with the above-ground production 

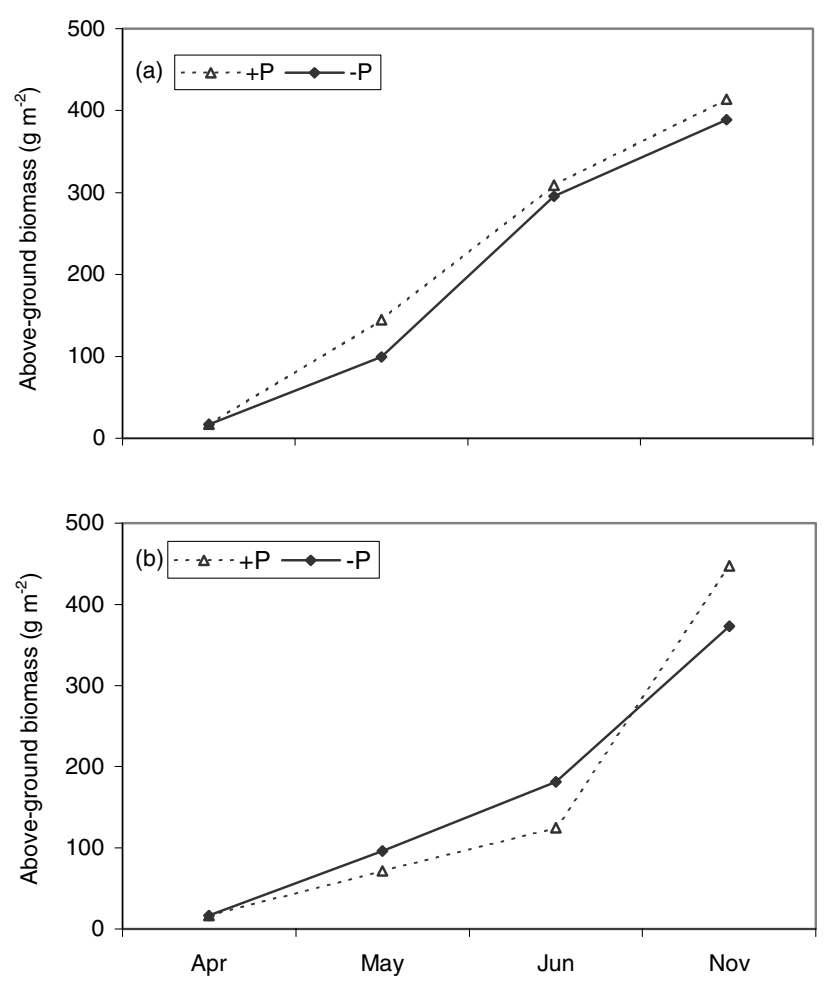

Figure 4. Harvested biomass in the second fertilization experiment after the first fertilizer application in April. With $\mathrm{N}$ addition (N and NP plots) (a). Without $\mathrm{N}$ addition (C- and P-plots) (b). In the $+\mathrm{N}$ treatments, differences between fertilized and control plots were significant in May, while in the $-\mathrm{N}$ treatments differences were significant both in May and in June.

in the fertilized plots being three-fold higher than in the control. Plots with $\mathrm{N}$ application initially show a significant increase in biomass production, while the P-plots were well below the control. But at the end of the growth season all treatments attained a similar above- ground biomass. All four grasses responded to NPKS addition, but their timing and growth patterns were fairly different. Paspalum chaffanjonii and Panicum laxum exhibit the opposite growth behaviour, which is enhanced by fertilization. The first species takes advantage of the first period of favourable water availability, after drought and before flooding, the second takes advantage of the second favourable water period, after flooding and before drought. Leersia hexandra seems to be less hindered by flooding, maintaining a high growth even when the soil is flooded, and indeed it is known to be a flood-tolerant grass. Axonopus purpusii has the peculiarity of showing significant growth even during the last 2 mo of the experiment, when high soil water potentials are the rule. This accords with $A$. purpusii being the only hyperseasonal savanna grass that is also important in seasonal, well-drained savanna ecosystems. These divergent responses suggest a temporal division of the critical resources, in this case nutrients, among the main savanna grass species. A similar temporal niche division among dominant grasses across the growing season has been reported as a generalized fact in Venezuelan seasonal savannas, but in this case the critical resources were both soil water and nutrients (Sarmiento 1983b).

NP application increased above-ground plant production in a comparable hyperseasonal savanna ecosystem in the Apure Llanos, and within the range of 100$300 \mathrm{~kg} \mathrm{ha}^{-1} \mathrm{~N}$ and $50-200 \mathrm{~kg} \mathrm{ha}^{-1} \mathrm{P}_{2} \mathrm{O}_{5}$ it was independent of the supplied amount (Tejos 1979). In all cases the increase in harvested material (clipped at $5-7 \mathrm{~cm}$ high) was around $40 \%$ above the control. NPS addition $\left(100 \mathrm{~kg} \mathrm{ha}^{-1} \mathrm{~S}\right)$ further increased savanna production by $15 \%$ over the NP treatment, the application of NPK $\left(150 \mathrm{~kg} \mathrm{ha}^{-1} \mathrm{~K}_{2} \mathrm{O}\right)$ only slightly increased plant production, whereas a NPKS application almost doubled savanna production (Tejos 1984). We may conclude

Table 2. Nitrogen concentration (\%) in the harvested biomass of Paspalum chaffanjonii, during the second fertilization experiment: mean \pm SD. The fertilizer was applied in April and November, after clipping the grassland. $P\left(F_{\text {Null }} \geq F_{\text {obs }}\right)$ for treatment, dates and interaction were $0.827,0.001$ and 0.001 respectively. As interaction was significant, the significance of dates was evaluated within levels of treatment. $\mathrm{P}\left(\mathrm{F}_{\mathrm{Null}} \geq \mathrm{F}_{\mathrm{obs}}\right)$ were 0.002 , $0.001,0.008$ and 0.007 for N, NP, P and C respectively, giving strong evidence of the influence of treatment on the differences among dates.

\begin{tabular}{lccrrr}
\hline & May 1998 & June 1998 & November 1998 & December 1998 & January 1999 \\
\hline $\mathrm{N}$ & $1.32 \pm 0.021$ & $0.89 \pm 0$ & $0.39 \pm 0.000$ & $1.56 \pm 0.035$ & $0.445 \pm 0.007$ \\
$\mathrm{NP}$ & $1.49 \pm 0.028$ & $1.01 \pm 0.014$ & $0.335 \pm 0.007$ & $1.58 \pm 0.021$ & $0.225 \pm 0.035$ \\
$\mathrm{P}$ & $1.26 \pm 0.007$ & $0.88 \pm 0.042$ & $0.52 \pm 0.240$ & $1.25 \pm 0.028$ & $0.875 \pm 0.007$ \\
$\mathrm{C}$ & $1.14 \pm 0.028$ & $0.885 \pm 0.007$ & $0.705 \pm 0.007$ & $1.36 \pm 0.014$ & $0.875 \pm 0.035$ \\
\hline
\end{tabular}

Table 3. Phosphorus concentration (P ppm) in the harvested biomass of the main grass species, 2 mo after fertilizer application: mean \pm SD. Fertilizer was applied in April. $\mathrm{P}\left(\mathrm{F}_{\mathrm{Null}} \geq \mathrm{F}_{\mathrm{obs}}\right)$ for treatment, species and interaction, calculated per month, were 0.02, 0.01 and 0.001 respectively. Different letters identify different groups of treatments and species at $\alpha=0.05$.

\begin{tabular}{lcccr}
\hline & $\mathrm{N}$ & $\mathrm{NP}$ & $\mathrm{P}$ & $\mathrm{C}$ \\
\hline Paspalum chaffanjonii & $1.10 \pm 0.07$ & $1.26 \pm 0.02$ & $1.05 \pm 0.06$ & $1.16 \pm 0.04$ \\
Panicum laxum & $0.86 \pm 0.04$ & $1.60 \pm 0.10$ & $1.35 \pm 0.03$ & $1.30 \pm 0.03$ \\
Leersia hexandra & $1.28 \pm 0.01$ & $1.47 \pm 0.03$ & $1.75 \pm 0.04$ & $1.45 \pm 0.02$ \\
Axonopus purpusii & $0.83 \pm 0.03$ & $0.70 \pm 0.02$ & $0.76 \pm 0.04$ & $0.66 \pm 0.04$ \\
& $\mathrm{a}$ & $\mathrm{b}$ & $\mathrm{b}$ & $\mathrm{a}$ \\
& & & $\mathrm{c}$ & $\mathrm{c}$ \\
\hline
\end{tabular}


that growth and primary production of flooded savannas, besides being constrained by several consecutive months of water deficiency and by shorter periods of water excess, are continuously constrained by a severe deficiency in soil nutrients, and that at least $\mathrm{N}, \mathrm{P}, \mathrm{K}$ and $\mathrm{S}$, seem to be implied in this limitation. The second experiment also showed that without $\mathrm{N}$ addition, the $\mathrm{P}$ fertilization does not improve grass growth or primary production, while $\mathrm{P}$ further increased the grassland performance when $\mathrm{N}$ was also added. Therefore, $\mathrm{N}$ may be considered the first limiting nutrient and $\mathrm{P}$ the second. Similar results were reported in the long-term Park Grass Experiment (Tilman et al. 1994) as well as in a long-term study in South African mesic grasslands where ANPP responded to the interaction of $\mathrm{N}$ and $\mathrm{P}$ as first and second limiting nutrients respectively (Fynn \& O'Connor 2005). We may consider that the hyperseasonal savanna ecosystem is so adapted to the nutrient conditions prevailing in highly dystrophic soils that an occasional nutrient pulse may act more as a disturbance than as a release from nutrient stress. The disturbance is rapidly controlled, and the system comes back to its normal nutrient economy and primary productivity.

\section{Soil and vegetation nitrogen pools}

The brief increase in soil mineral $\mathrm{N}$ during the peak of rains may be related to the almost negligible plant growth when the soil is water saturated or flooded (Sarmiento et al. 2004), and possibly also to a decrease in microbial biomass of aerobic micro-organisms during the mostly anoxic period. The fact that the fertilized plots did not maintain higher mineral-N concentration than the control plots strongly suggests that most of the fertilizer$\mathrm{N}$ (urea) has rapidly been absorbed by roots, immobilized in the microbial biomass or lost.

The amount of $\mathrm{N}$ in the harvested biomass during the entire growth season in NPKS fertilized plots was four times higher than in the control. The nitrogen use efficiency ( $\mathrm{NUE}=\mathrm{g}$ of harvested biomass/g of $\mathrm{N}$ in harvested biomass) of $P$. chaffanjonii in the NPKS treatment decreased $25 \%$ below the control plants; that is, in plots with a larger $\mathrm{N}$ supply, under less severe N-limitation, savanna grasses spend larger amounts of $\mathrm{N}$ per unit of biomass accumulated, i.e. they have a lower $\mathrm{C} / \mathrm{N}$ ratio (Table 4). This means that, when fertilized, this

Table 4. Mean nitrogen use efficiency during the growing season in Paspalum chaffanjonii (N NUE: $g$ of harvested biomass/g of N in biomass) and mean $\mathrm{C} / \mathrm{N}$ ratio (considering $45 \% \mathrm{C}$ in biomass).

\begin{tabular}{lcccc}
\hline & Biomass $\left(\mathrm{g} \mathrm{m}^{-2}\right)$ & $\mathrm{N}\left(\mathrm{g} \mathrm{m}^{-2}\right)$ & $\mathrm{N} \mathrm{NUE}$ & $\mathrm{C} / \mathrm{N}$ \\
\hline NPKS & 368 & 6.9 & 53.4 & 24.0 \\
Control & 115 & 1.6 & 71.6 & 32.2 \\
\hline
\end{tabular}

species does not attain a larger ANPP, but its biomass is enriched in nitrogen. But why does a higher leaf $\mathrm{N}$ concentration not result in higher assimilation rates and hence in higher productivity? Probably because the higher $\mathrm{N}$ concentration and assimilation also lead to higher leaf turnover rates, higher decomposition and therefore the increased productivity does not translate into a larger cropped biomass at the end of the growing season.

Another point worth noticing is that the excess of $\mathrm{N}$ in the harvested biomass of fertilized plants at the end of the NPKS fertilization experiment (the difference between the amount of $\mathrm{N}$ in fertilized and control plants) was about one third the amount of added $\mathrm{N}\left(5.3 \mathrm{~g} \mathrm{~m}^{-2} \mathrm{vs.} 15 \mathrm{~g} \mathrm{~m}^{-2}\right)$. That is, even considering that this extra $\mathrm{N}$ accumulated in the fertilized plants entirely proceeds from the fertilizer $\mathrm{N}$ and not from the native soil $\mathrm{N}$, these figures show that grasses were only able to absorb a minor part of the fertilizer $\mathrm{N}$. The unutilized $\mathrm{N}$ might be immobilized in the soil microbial biomass or lost through deep leaching, volatilization or denitrification.

\section{Phosphorus pools in soil and grasses}

Phosphorus fertilization did not lead to higher ANPP. In fact, none of the three fertilization treatments in the second experiment improved ANPP. In the short-term ( $2 \mathrm{mo}$ ), significant differences in $\mathrm{P}$ concentration between treatments and species were evident but the treatment under which it was higher depended on the species, and which species had the higher P concentration depended on the treatment. Thus for instance, L. hexandra was the only species reaching a higher $\mathrm{P}$ concentration in $\mathrm{P}$ plots than in C-plots, and P. laxum was the single species showing a higher $\mathrm{P}$ concentration in NP-plots than in Cplots. Thisfact further points out the differential behaviour of each species that surely contributes to the partition of niches along a nutrient axis. In this experiment, a modest amount of $\mathrm{P}$ was applied $\left(2 \mathrm{~g} \mathrm{~m}^{-2}\right)$, a quantity roughly equivalent to $15 \mathrm{ppm}$ of available $\mathrm{P}$ in the upper $10 \mathrm{~cm}$ of soil, which represents a 15-fold increase in the available P stock in this soil layer (Lopez-Hernández 1995). This soluble $P$ seems to be rapidly sequestered from the soil solution by micro-organisms or chemical sorption (Frossard et al. 1995), or otherwise, the lack of other elements is limiting $\mathrm{P}$ absorption by grasses, and therefore the addition of $\mathrm{P}$ does not result in any evident effect either in primary production or in $\mathrm{P}$ accumulation by savanna grasses.

\section{$\mathrm{N}$ and $\mathrm{P}$ as limiting factors in hyperseasonal savannas}

As was mentioned above, nitrogen limitation seems to be a generalized constraint to tropical savanna 
ecosystems, because low atmospheric inputs and high outputs have led to a tightly balanced cycle. Besides, any increase in savanna above-ground production represents a corresponding increase in volatilization losses during savanna fires. After a pulse of fertilizer $\mathrm{N}$, the pool of soil mineral $\mathrm{N}$ becomes rapidly depleted. Phosphorus may also constrain growth and primary production but when applied as fertilizer it rapidly becomes sorbed in mineral and organic bound forms. In the Apure Llanos, inputs of $\mathrm{P}$ in precipitation are almost twice as high as the outputs through drainage water, both figures being quite small so that the annual gains only amount to $9 \mathrm{mg} \mathrm{m}^{-2}$ (Lopez-Hernández et al. 1994). P losses in particulate materials in drainage water are much more important, amounting to almost $200 \mathrm{mg} \mathrm{m}^{-2} \mathrm{y}^{-1}$. These losses cannot be compensated by weathering of the parent material, since the old alluvium on which these soils have evolved has been thoroughly weathered before sedimentation. Then, we may expect that $\mathrm{P}$ will become increasingly limiting to primary production in this savanna ecosystem and that mechanisms increasing $\mathrm{P}$ use efficiency were occurring.

In acid tropical soils, the $\mathrm{H}_{2} \mathrm{PO}_{4}^{-2}$ anion rapidly forms poorly soluble compounds with $\mathrm{Al}^{3+}$ and $\mathrm{Fe}^{3+}$ (Bohn et al. 2001, Sanchez 1976). Therefore, after any P addition, very little soil $\mathrm{P}$ remains in soluble form for longer. In the Apure hyperseasonal savanna we are dealing with, total and soluble $\mathrm{P}$ concentrations in the topsoil are quite low, $260-270 \mathrm{mg} \mathrm{kg}^{-1}$ and $1.3 \mathrm{mg} \mathrm{kg}^{-1}$ respectively (Lopez-Hernández 1995), both because of soil acidity and the abundance of $\mathrm{Al}$ and $\mathrm{Fe}$ oxides and hydroxides. Besides, in many seasonally flooded ecosystems $\mathrm{P}$ concentration in the soil solution increases upon flooding due to several factors promoting solution of fixed P, but apparently this does not occur in tropical acid soils rich in ferric ions; in these cases soil water saturation does not cause a noticeable increase in P solubilization (Sanchez 1976).

The dynamics of $\mathrm{P}$ in highly weathered tropical soils just begin to be understood, mainly through labelled-P techniques and experiments. When savanna oxisols in the Brazilian cerrado are fertilized, most of the fertilizer $P$ is recovered in weakly bound fractions through sequential extraction (Lilienfein et al. 1999). In another tropical savanna on an Oxisol in the Colombian Llanos, where soil $P$ fractions $(0-20 \mathrm{~cm})$ were obtained through sequential $\mathrm{P}$ extraction combined with ${ }^{33} \mathrm{P}$ labelling (Buehler et al. 2002), the total amount of $P\left(172 \mathrm{mg} \mathrm{kg}^{-1}\right)$ was fractioned into pools differing in plant availability, ranging from soluble $\mathrm{P}\left(0.9 \mathrm{mg} \mathrm{kg}^{-1}\right)$ to residual, to very recalcitrant, almost permanently adsorbed $\mathrm{P}\left(44 \mathrm{mg} \mathrm{kg}^{-1}\right)$, with most of the soil $\mathrm{P}$ in fractions of intermediate availability. When fertilizer $P$ was added, these intermediate fractions were again the main sink for the applied phosphorus. In a tropical forest on an andosol in Hawaii, with low $\mathrm{P}$ availability, where ${ }^{32} \mathrm{PO}_{4}$ was used as a marker, phosphate was added either at low concentration (10 ppm) or as a pulse adding high fluxes of $\mathrm{P}$ to the soil solution $(100 \mathrm{ppm})$, sorption and microbial immobilization consumed most added P within 30 min (Olander \& Vitousek 2004). Furthermore, P fluxed from the sorbed pool into the microbial pool when an increase in the microbial biomass was induced, suggesting that the microbiota may play a crucial role in the dynamics of soil $\mathrm{P}$ and in their availability to plants. In our case, the added $\mathrm{P}$ was not assimilated by savanna grasses at least in the above-ground biomass and during the first growing cycle after fertilization.

Besides N and P limitations, this flooded savanna is also limited by potassium and sulphur availability. The effect of NPKS addition on savanna production and its comparison with NPK application, have been reported in Brazil (Goedert 1986), with increments in the order of $4 \%-30 \%$ when $S$ was added to the fertilizer. In the Apure Llanos, primary production of a flooded savanna increased when NPKS was applied, over a similar treatment but excluding sulphur (Tejos 1984). However no data are available on the effect of $\mathrm{K}$ and $\mathrm{S}$ in the absence of $\mathrm{N}$ and $\mathrm{P}$ fertilization. The effect of $\mathrm{K}$ and $\mathrm{S}$ deficiency may be assessed by comparing the results of the NPKS and NP experiments. The total harvested biomass in the NPKS treatment was almost three-fold that of the control, while in the NP treatment it was similar to the control. This result strongly suggests the limiting role of $\mathrm{K}$ and/or $\mathrm{S}$ on the savanna above-ground production.

\section{CONCLUSIONS}

Above-ground primary production in hyperseasonal savannas is sharply constrained by nutrient deficiencies, further limiting plant growth and productivity beyond the strong limitations imposed by drought and water excess. Application of single elements like $\mathrm{N}$ or $\mathrm{P}$, at the start of the growing season, does not improve plant growth and primary production, addition of NP may have a noticeable effect, whereas NPKS fertilization leads to a three-fold increase in plant production. Fertilization does not affect primary production when applied before the second growth peak, after flooding. Despite differences in growth rates, the four most important grasses in the analysed ecosystem behave as the total grass layer, suggesting that all are constrained by a restricted nutrient supply, but each grass showed a different seasonal growth pattern, suggesting a temporal division of the niche as a response to nutrient availability.

Nitrogen accumulated in the harvested biomass during the growth season shows a four-fold increase over the control plants when NPKS is applied. Apparently the amount of $\mathrm{P}$ accumulated in the cropped biomass does 
not increase in the $\mathrm{P}$ and NP treatments in comparison with the control plants. Under the moderate amounts of $\mathrm{N}$ added to the soil, the maximum $\mathrm{N}$ accumulated in the above-ground biomass during the growth season (in the NPKS treatment) represents about half the total N in the fertilizer, whereas fertilizer $P$ does not increase the $\mathrm{P}$ amount in the cropped above-ground biomass.

With the moderate amounts of $\mathrm{P}$ added to the soil, $\mathrm{P}$ accumulation in the $\mathrm{P}$ and control treatments were identical, strongly suggesting that the fertilizer $\mathrm{P}$ was not used by the grasses, being probably immobilized or adsorbed and therefore not available to plants, at least in this short term. However, the increasing growth rates of grasses in this treatment during the 7 following months suggest that some P fluxed from these pools to the soil solution and to plants. In this way soil biological processes intervene to make geochemically fixed $\mathrm{P}$ in the soil available to savanna vegetation.

\section{ACKNOWLEDGEMENTS}

This research is part of the European Union INCO-DC International Cooperation with Developing Countries Project 'Ecological Basis for the Sustainable Management of Flooded Tropical Ecosystems' (Contract number ERBIC18CT960087). We acknowledge the participation in the field work of several members of the Instituto de Ciencias Ambientales y Ecológicas, particularly Dimas Acevedo, Rodiney Mauro and Nelson Marquez. We are grateful to Prof. Valério Pillar for his advice on statistical procedures and for providing the software MULTIV for statistical analyses.

\section{LITERATURE CITED}

AOAC. 1990. Nitrogen (Total) (Crude Protein) in plants. Kjeldahl methods. Pp. 59-76 in Official methods of analysis of the Association of Official Analytical Chemists. (Fifteenth edition). AOAC Inc, Gaithersburg.

BOHN, H., MCNEAL, B. \& O'CONNOR, G. 2001. Soil chemistry. (Third edition). John Wiley \& Sons, New York. 320 pp.

BUEHLER, S., OBERSON, A., RAO, I. M., FRIESEN, D. K. \& FROSSARD, E. 2002. Sequential phosphorus extraction of a ${ }^{33} \mathrm{P}$-labeled oxisol under contrasting agricultural systems. Soil Science Society of America Journal 66:868-877.

DELAUNE, R. D., SMITH, C. J. \& SARAFYAN, M. N. 1986. Nitrogen cycling in a freshwater marsh of Panicum hermitomon on the deltaic plain of the Mississippi river. Journal of Ecology 74:249-256.

FISHER, M. J., LASCANO, C. E., VERA, R. R. \& RIPPSTEIN, G. 1992. Integrating the native savanna resource with improved pastures. Pp. 75-99 in Pastures for the tropical lowlands, CIAT's Contribution. CIAT, Cali, Colombia.

FROSSARD, E., BROSSARD, M., HEDLEY, M. J. \& THERELL, M. R. 1995. Reactions controlling the cycling of P in soils. Pp. 107-137 in
Tiessen, H. (ed.) Phosphorus in the global environment, transfers, cycles and management. Scope 54, J Wiley, Chichester.

FROST, P. G. H. \& ROBERTSON, F. 1987. The ecological effects of fire in savannas. Pp. 93-140 in Walker, B. H. (ed.). Determinants of tropical savannas. IRL Press, Oxford.

FYNN, R. W. S. \& O'CONNOR, T. G. 2005. Determinants of community organization of a South African mesic grassland. Journal of Vegetation Science 16:93-102.

GOEDERT, W. J. 1986. Solos dos cerrados. Tecnologías e estratégias de manejo. EMBRAPA-Nobel, São Paulo. 422 pp.

HÉTIER, J. M., SCHARGEL, R., VALLEJO-TORRES, O., SARMIENTO, G. \& GOMEZ, C. 1992. Les sols de savane des llanos vénézuéliens et le sol ferrugineux tropical de Barinas. Cahiers ORSTOM, série Pédologie 27:17-202.

LILIENFEIN, J., WILCKE, W., NEUFELDT, H., AYARZA, M. A. \& ZECH, W. 1999. Phosphorus pools in bulk soil and aggregates of differently textured Oxisols under different land-use systems in Brazilian Cerrados. Pp. 159-172 in Thomas, R. \& Ayarza, M. A. (eds.). Sustainable land management for the oxisols of Latin American savannas. Centro Internacional de Agricultura Tropical, Cali, Colombia.

LOPEZ-HERNÁNDEZ, D. 1995. Balance de elementos en una sabana inundada, Mantecal, Estado Apure, Venezuela. Acta Biológica Venezolana 15:55-88.

LOPEZ-HERNÁNDEZ, D., GARCIA, M. \& NIÑO, M. 1994. Input and output of nutrients in a dyked flooded savanna. Journal of Applied Ecology 31:303-312.

MANLY, B. F. J. 1997. Randomization, bootstrap and Monte Carlo methods in biology. (Second edition). Chapman \& Hall/CRS Press, London. $424 \mathrm{pp}$.

MEDINA, E. 1987. Nutrients. Requirements, conservation and cycles of nutrients in the herbaceous layer. Pp. 39-59 in Walker, B. H. (ed.). Determinants of tropical savannas. IRL Press, Oxford.

MEDINA, E. \& SILVA, J. F. 1990. Savannas of northern South America: a steady state regulated by water-fire interactions on a background of low nutrient availability. Journal of Biogeography 17:403-413.

OLANDER, L. P. \& VITOUSEK, P. M. 2004. Biological and geochemical sinks for phosphorus in soil from a wet tropical forest. Ecosystems 7:404-419.

PILLAR, V. D. 2004. MULTIV, software for multivariate exploratory analysis, randomization testing and bootstrap resampling: User's Guide v. 2.3.10. UFRGS, Porto Alegre (available at http://ecoqua. ecologia.ufrgs.br/).

PILLAR, V. D. \& ORLÓCI, L. 1996. On randomization testing in vegetation science: multifactor comparisons of relevé groups. Journal of Vegetation Science 7:585-592.

RAMIA, M. 1997. Ecología de las sabanas del Estado Cojedes: relaciones vegetación-suelos en sabanas húmedas. Colección Cuadernos FLASA, Serie Ciencia y Tecnología No 9, Fundación La Salle de Ciencias Naturales, Caracas, 70 pp.

SANCHEZ, P. 1976. Properties and management of soils in the tropics. John Wiley \& Sons, New York. 618 pp.

SARMIENTO, G. 1983a. The savannas of tropical America. Pp. 245288 in Bourlière, F. (ed.). Ecosystems of the World. 13. Tropical Savannas. Elsevier, Amsterdam. 
SARMIENTO, G. 1983b. Patterns of specific and phonological diversity in the grass community of the Venezuelan tropical savannas. Journal of Biogeography 10:373-391.

SARMIENTO, G. 1984. The ecology of neotropical savannas. Harvard University Press, Cambridge, 235 pp.

SARMIENTO, G. \& PINILLOS, M. 2000. A conceptual model relating ecological constraints to livestock production in tropical American seasonal savannas. Pp. 295-314 in Mander, U. \& Jongman, R. H. G. (eds.). Consequences of land use changes. WIT Press, Southampton.

SARMIENTO, G. \& PINILLOS, M. 2001. Patterns and processes in a seasonally flooded tropical plain: the Apure Llanos, Venezuela. Journal of Biogeography 28:985-996.

SARMIENTO, G., PINILLOS, M., PEREIRA DA SILVA, M. \& ACEVEDO, D. 2004. Effects of soil water regime and grazing on vegetation diversity and production in a hyperseasonal savanna in the Apure Llanos, Venezuela. Journal of Tropical Ecology 20:209-220.
SCHARGEL, R. \& GONZALEZ, J. 1972. Estudio agrológico preliminar sectores Bruzual y Mantecal, Estado Apure. Ministerio de Obras Públicas, Caracas. 144 pp.

SOLBRIG, O. T., MEDINA, E. \& SILVA, J. F. 1995. Determinants of tropical savannas. Pp. 31-41 in Solbrig, O. T., Medina, E. \& Silva, J. F. (eds.). Biodiversity and savanna ecosystem processes. A global perspective. Springer, Berlin.

TEJOS, R. 1979. Efecto del nitrógeno y fósforo sobre la producción de forraje de una sabana. Agronomía Tropical 29:1-14.

TEJOS, R. 1984. Efecto del potasio y azufre sobre el pastizal nativo de una sabana. I. Producción. Zootecnia Tropical 2:74-89.

TILMAN, D., DODD, M. E., SILVERTOWN, J., POULTON, P. R., JOHNSTON, A. E. \& CRAWLEY, M. J. 1994. The park grass experiment: insights from the most long-term ecological study. Pp. 287-303 in Leigh, R. A. \& Johnston, A. E. (eds.). Long-term experiments in agricultural and ecological sciences, CAB International, Wallingford. 